\title{
Study of Shark Kidney Histology (Carcharhinus sorrah)
}

\author{
Zakia Darajat \\ Biology Department, Faculty of Science and Technology, UIN Sunan Kalijaga Yogyakarta \\ J1. Marsda Adisucipto No 1 Yogyakarta 55281, Indonesia. Tel. +62-274-540971, Fax. +62-274-519739. \\ Email: darajatzakia@gmail.com
}

\begin{abstract}
Darajat Z. 2017. Study of Shark Kidney Histology (Carcharhinus sorrah). Proc Internat Conf Sci Engin 1: 67-69. Shark is a fish widespread in the tropical Indo-Pacific Ocean with a depth of 75 to 130 meters. Shark is a cartilaginous fish (Elasmobranchii). The fish is an ancient animal species that are still alive and also have different characteristics with bony fishes. Research on the histology of the shark's kidneys is still rare. The purpose of this study was to describe the histology of the shark kidneys (Carcharhinus sorrah). In this study we used one individual shark (Carcharhinus sorrah) from Depok Beach, Yogyakarta. The method used in this research was paraffin method with Hematoxylin-Eosin staining. From microscopic observation, the kidneys consist of glomerular parts, proximal tubules, distal tubules and lymphoid tissue.
\end{abstract}

Keywords: Glomerulus, Histology, Kidney, Shark (Carcharhinus sorrah)

\section{INTRODUCTION}

Fish are poikoloterm (cold-blooded) vertebrates that live in water and breathe with gills. Fish are the most diverse group of vertebrates with more than 27,000 species worldwide. Taxonomically, fish belonging to the paraphyletic group whose kinship relationship is debatable. Fish are divided into jawless fish (Agnatha class, 75 species including lampreys and hag fish), cartilaginous fish (Chondrichthyes class, 800 species including sharks and rays) and the remainder are classified as bony fishes (Osteichthyes class). (Brotowidjoyo, 1989).

The fish belonging to the Chondrichthyes class have a ventral mouth, and are supported by the jaw. Skeleton are of cartilage, skin covered with placoid scales (derived from mesoderm and ectoderm combinations). There are two pairs of fins, while the caudal fin is mostly heterocercal (larger dorsal lobes). Pharynx with 5-7 gill slits. Some notochord are replaced with complete vertebra. In adult fish there is mesonephros. In the kidneys there is a portal system. In the intestine there is a spiral valve. Separate sex, external and internal fertilization. Practically all life in the sea, for example: shark (Squalus sp.), Stingray (King sp.) And chimera (Chimaera sp.) (Brotowidjoyo, 1989).

Chondrichthyes, sharks and their relatives, are called cartilaginous fish because they have relatively flexible endoskeleton made of cartilage instead of bones. Jaws and paired fins develop well in cartilaginous fish (Campbell, 1999). Shark (Carcharhinus sorrah) have long and rounded snout, large circular eyes, lack of spines on dorsal fins and anal fins, no soft fingers on dorsal and anal fins, very short $2^{\text {nd }}$ dorsal fin. Distribute in the ocean and tropical Indo-Pacific Ocean, with depths of about 75 to 130 meters.

Histology is a branch of biology that studies the structure of cells and tissue (Banks, 1986). According
Tresni et.al. (2007), the kidneys are the body organs that play a role in maintaining the balance system and selecting the body's metabolism. The selection process is done by filtering the body fluids that pass through the kidneys. Filtering is done by the kidney part known as the nephron. Nephrons are tubules that are approximately $6 \mathrm{~cm}$ long and include the smallest part of the kidney that consists of glomerulus, proximal tubules, distal tubules and urinary tubules. Each kidney has approximately 1,000,000 nephrons for 24 hours to filter about 170 liters, the renal artery carries pure blood from the aorta to the kidneys.

The fish kidney are located in the retroperitoneal position of the ventral part of the spine, below the vertebral column (Ferguson, 1989 in Damayanti, 2010). Kidneys are light brown or black, their shape varies by species. Kidney is an organ excretion in fish. In fish, the kidneys serve to maintain the acid-base balance of the body fluids and regulate the viscosity of the urine, so that the observation of the kidney structure is important to know the bonding of tissue cells and the arrangement or matrix that binds them. Studies on the histology of the shark's kidneys are still rare. It is interesting to study histology of the shark's kidneys. The purpose of this research is to know the histological structure of the shark's kidneys (Carcharhinus sorrah).

\section{MATERIALS AND METHODS}

This research was done on March 20 to April 29, 2016. This research was conducted in laboratory of Zoology Faculty of Science and Technology UIN Sunan Kalijaga Yogyakarta. The equipments used in this research are surgical tools, glassware, microtom, warmer slide, paraffin oven, microscope, slide and cover glass, tweezers, and tissue. The materials used in this study were shark (Carcharhinus sorrah) obtained from Depok 
beach, bouin solution, chloroform, alcohol 60\%, 70\%, $80 \%, 90 \%, 96 \%$, and absolute, toluene, xylol, hematoxylin, eosin and entellan.

The shark was sacrified using chloroform and then dissected, the kidneys were cut with a thickness of 0.5 $\mathrm{cm}$. The organ was fixed using a bouin solution and soaked for 24 hours. The organ was then washed in running water for 1 hour. The next process is dehydration. Dehydration is done by using a stratified alcohol solution, i.e., from low percentage alcohols to high percentage alcohols. Alcohol used is alcohol 60\%, $70 \%, 80 \%$, 90\%, 96\% and absolute alcohol. All treatments are repeated as much as one repetition and are shaken. Then the organ were cleared using toluene, and soaked for 24 hours.

Furthermore, the animal organ is infiltrated using paraffin: toluene (50:50) for 1 hour in an oven with a temperature of $65^{\circ} \mathrm{C}$. Then transferred to paraffin I for 2 hours, paraffin II for 3 hours, and paraffin III for 3 hours. The next stage is the process of embedding by embedd animal organs in paraffin blocks. The next stage is done by slicing the organ with a thickness of approximately 4-5 micrometers, then pasted on a slide that has been smeared with albumin glycerine, then drop aquades, and heated over a warmer slide with a temperature of $45^{\circ} \mathrm{C}$. Next step was staining process. The staining process begins with the deparafinization process using xylol 1 and xylol 2, then the rehydration was done, then put in the hematoxylin solution. Then washed with running water. Soaked into $60 \%$ alcohol. The next process was staining with eosin solution. Next step was dehydration process. Then soaked alcohol absolute. After that clearing in xylol 1 and xylol 2. The last step was mounting using entellan then closed using a cover glass. The organ is labeled and observed using a microscope with magnification 40x, 100x, and 400x.

\section{RESULTS AND DISCUSSION}

\section{Anatomy of the Shark's Kidney}

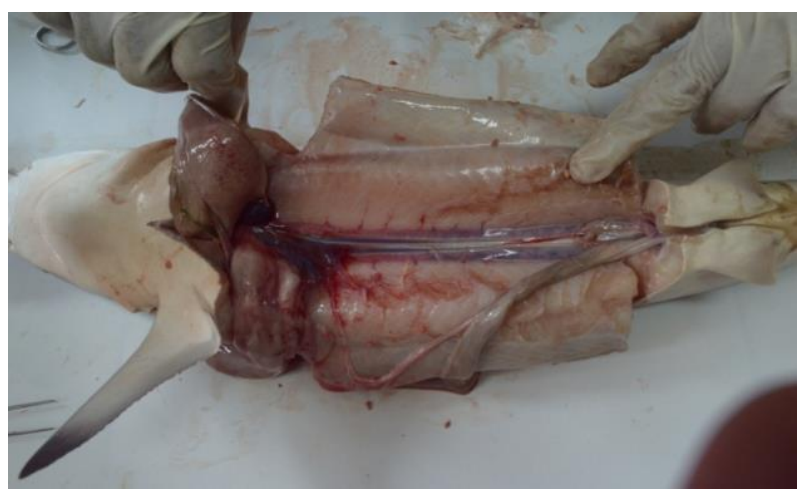

Figure 1. Anatomy of the shark's kidney (Carcharhinus sorrah).

Fish kidney are generally located between the vertebral column and the swim bladder, above the abdominal cavity, below the spine and the dorsal aorta (Takashima, 1995). Sharks kidney are ussually red- black color. The shape of the fish's kidneys varies by species. The fish kidney consists of the head and body of the kidney. Embryologically, the kidney head is obtained from the pronephros form, and the body (body) of the kidney is mesonephros. The kidney head is the anterior portion of the kidney and consists of lymphoid tissue, whereas many nephrons and interestrial lymphoid tissue are present in the body of the kidneys.

\section{The Histology of the Shark's Kidneys}

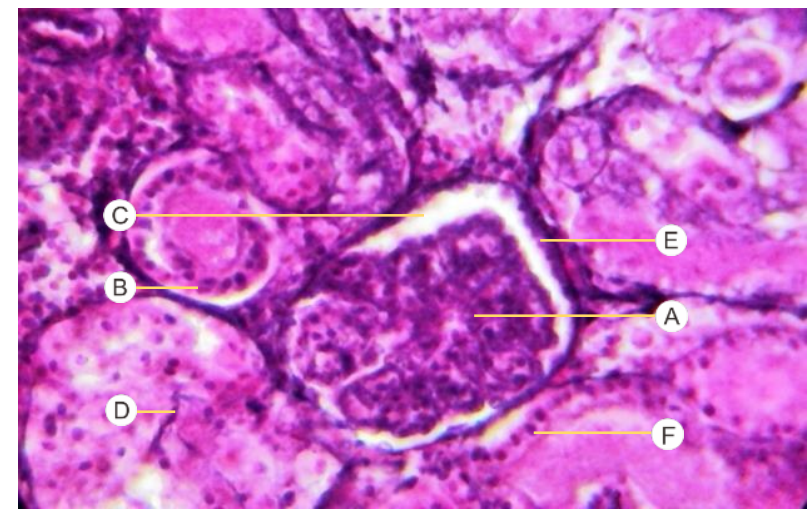

Figure 2. Shark renal organ histology (Carcharhinus sorrah). A Glomerulus, B. Renal tubule distal C. Capsule space, D. Lymphoid tissue, E. Parietal layer, F. nucleus cell.

The method used is paraffin method by using Hematoxylin-Eosin staining. Haematoxylin is an alkaline natural dye that will dye the acidic tissue and give the blue color to the cell nucleus. Eosin is a synthetic acidic dye that will color the basic components in tissue that is contained in cytoplasmic proteins so that the cytoplasm is red/pink.

In the transversal section, 40x10 magnification (Figure 2), there are glomeruli, renal tubule, capsule chamber, lymphoid tissue, parietal layer and cell nucleus. Glomerulus possesses a round shape. While the renal tubule is a thin layer of epithelium with long cilia and small narrowed small vessels in the kidney that can collect and transport urine from the nephron to the larger vessels connected to the renal calyses.

According to Edwards (1928), in Chondrichthyes fish, the kidneys are a pair of very long brown ribbons on each side of the roof line of the pleuroperitoneum (retroperitoneum) space. In several different parts, the thickness of the kidneys is different. The front is thinner, while the back is thicker and serves as an apparattus of excretion. Kidney function begins in the glomerulus. Glomerulus is a capillary lobulated beam, before entering the glomerulus, the afferent arteriole is divided into several distorted capillars, which form the ultrafiltrate forming of the plasma. Ultrafiltrate will enter Bowman's capsule and go to the lumen of the tubule. When filtration occur through various segments of the tubules, there are changes in volume and composition of the filtration fluid as a result of the reabsorption and secretion processes along the tubules (Siregar, 1995). 
According to (1995), lymphoid tissue and intertubular tissue of the kidney is a hematopoietic tissue of Teleostei. Lymphoid tissue is part of the interestrial tissue in the fish's renal portion, and is present only in fish. Hematopoietic tissue is a network capable of forming red blood cells, white blood cells and blood clots.

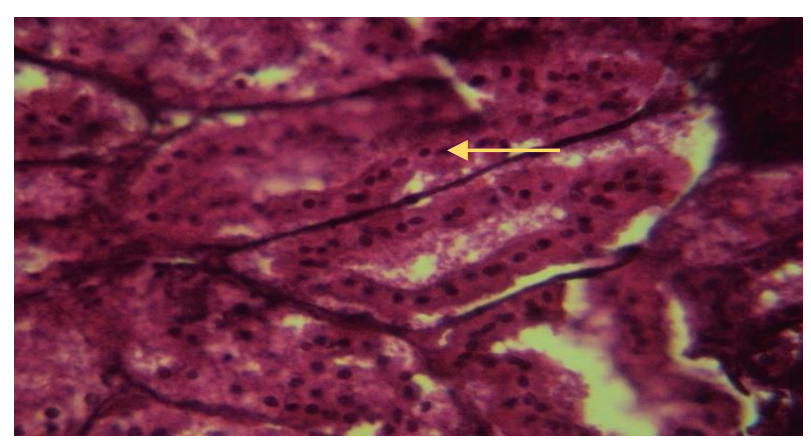

Figure 3. Proximal tubules in sharks (Carcharhinus sorrah).

According to Takashima (1995), Tubulus serves to change the fluid filtered urine. Tubules play an important role in maintaining water balance. Renal tubules are very thin and short on the neck (neck segment). The proximal contortus tubule is the longest tubule, the cells are cuboid and have a characteristic that have brush border. The distal contortus tubules are shorter than the proximal contortus tubules and there are no brush borders. The cells are also cuboid-shaped with the core often located close to the apex (Genester, 1994)

\section{CONCLUSIONS}

Observation of the histological structure of the shark's kidneys (Carcharhinus sorrah) under microscope reveal glomerular parts, distal renal tubule, proximal, capsule chamber, lymphoid tissue, parietal lining, and cell nucleus

\section{REFERENCES}

Banks. W.J. 1986. Applied Veterinery Histology, $2^{\text {nd }}$ ed.USA. The Williams and Wilkins Company.

Brotowidjoyo, M. D. 1989. Zoologi Dasar. Jakarta: Erlangga

Campbell.Neil A. 1999. Biologi edisi kelima jilid 2. Jakarta: Erlangga.

Damayanti, F.N. 2010. Pengaruh Pencemaran Logam Berat terhadap Kondisi Histologi Ikan Nila (Oreochromis niloticus Linn) dalam Karamba Jaring Apung Di Blok Jangari Waduk Cirata. Skripsi. Universitas Padjadjaran. Jatinangor.

Edwards, J. G. 1928. Studies on aglomerular and glomerular kidneys I. Anatomical. The American Journal of Anatomy 42:75-108.

Genester, F. 1994. Buku Teks Histologi. Jilid 2. Binarupa Aksara. Jakarta. hal: 208-224.

Siregar, H. 1995. Fisiologi Ginjal. Edisi ketiga. Bagian Ilmu Faal. Fakultas Kedokteran. Universitas Hasanuddin. Unjung Pandang

Takashima \& T. Hibiya. 1995. An Atlas of Fish Histology. Normal and Pathological Features Fumio. Gustav Fischer Verlag. Stuggart. New York.

Tresnati, Joeharnanai, M. Iqbal Djawad, Siti Bulqish. 2007. Kerusakan Ginjal Ikan Kembang (Dasyatis kuhli) Yang Diakibatkan oleh Logam Berat Timbel $(\mathrm{Pb})$. Sains dan Teknologi. No.3 edisi ke-3 FKIP: Universitas Hasanudin. 
THIS PAGE INTENTIONALLY LEFT BLANK 